RAD Conference Proceedings, vol. 2, pp. 212-216, 2017

www.rad-proceedings.org

\title{
INFLUENCE OF DATA VISUALIZATION OF TEMPOROMANDIBULAR JOINT ON THE FORMATION OF CLINICAL GROUPS
}

\author{
Oleg Slesarevi", Ivan Bayricov¹, Dmitry Trunin'1, S. Abul'khanov²,3, N. Kazanskiy²,3
}

${ }^{1}$ Federal State Educational Institution of Higher Education "Samara State Medical University" of the Ministry of Health of the Russian Federation, Samara, Russia

${ }^{2}$ Samara National Research University Named After Academician S.P. Korolev, Samara, Russia

3Image Processing Systems Institute - Branch of the Federal Scientific Research Centre "Crystallography and

Photonics" of Russian Academy of Sciences, Samara, Russia

\begin{abstract}
The objective of this study was an analysis of the patient complaints of a structure and the nature of the formation of clinical groups for the study of patients with temporomandibular disorders (TMD). We examined 28 men and 148 women with TMD. We analyzed 604 tomographic images. Statistical processing included cross tables and chi-square analysis. Twenty-eight percent of the study population was followed up in a general clinical network, presenting with facial pain. Dental clinics established primary clinical diagnoses: arthrosis and arthritis (71\%), dislocation or subluxation of the temporomandibular joint head (16.5\%), and/or temporomandibular joint dysfunction (12.5\%). X-rays showed the combination of functional disorders (75\%) and degenerative dystrophic changes (67\%) of the temporomandibular joint; the $x$-ray norm was observed in $9 \%$ of cases. By TMJ visualization, we established the clinical features of females with TMD, depending on the reproductive stage. For patients in puberty, joint mobility was limited $(44.4 \%, p=0.045)$ compared with head dislocation, and arthritis $(p=0.024)$ was predominant. For patients in the early reproductive stage, head subluxation $(48.5 \%, p<0.010)$ was found in all detected pathologies except deforming arthrosis. For patients in the late reproductive stage and perimenopause, half of the examined patients had deforming arthrosis $(52.8 \%$ in the late reproductive stage, $p<0.01$, for all detected pathologies, except for limited joint mobility; $50 \%$ in perimenopause, $p<0.05$, with radiologic norms, dislocation of the head, and arthritis). In postmenopausal women, arthritis and sclerotic arthrosis were noted (30.8\% and $27.8 \%$, respectively). Structure of the patient complaints and the nature of the formation of clinical groups of patients with $T M D$ were determined by the place of primary treatment, specialization of the institution, and the level of techniques of primary diagnosis of TMD. This affected the patients' quality of treatment and is a cause of chronic (58\%) TMD.
\end{abstract}

Key words: Temporomandibular disorders, temporomandibular joint, tomography of temporomandibular joint, dysfunction of temporomandibular joint

DOI: $10.21175 /$ RadProc.2017.43

\section{INTRODUCTION}

Temporomandibular disorders (TMD) are among the most prevalent non-odontogenic pain syndromes of the temporomandibular area, and are considered to be a variant of the musculoskeletal pain syndrome. Epidemiological studies have revealed problems related to the TMD in $25 \%$ of the population [1], but only $3 \%$ to $7 \%$ seek medical aid [2]. Symptoms are associated, in $70 \%$ of cases, with the pain syndrome, disorders of mandibular mobility, and morphofunctional changes in the temporomandibular joint (TMJ) [3]. Women complain of TMD symptoms much more frequently than do men, within the range from $2: 1$ to $8: 1$ [4].

In spite of considerable advances in the study of etiology and pathogenesis of the TMD, the pain syndrome remains the key factor inducing a patient to seek medical care, and influences perspectives of therapy. It has been stated that the quality of denture occlusion and muscular function are the complex primary causes of the pain syndrome in TMD [5]. Randomized multidimensional studies have not confirmed the determinative influence of the occlusive factors on the etiopathogenesis of the TMD [6].

It has been convincingly demonstrated that stress and muscular tension are the triggers of myofascial pain and joint pain in the TMD $[7,8]$. Any myalgia, primary or secondary, concerning intra-articular lesions, leads to changes in the vector of the muscular strength that determines mandibular motion [9], dislocation of denture occlusion contacts [10], and disorders of the anatomical relation of the TMD elements [11]. A specific, versatile picture of the manifestation of the disease leads to incorrect patient routing, mistakes in diagnosis and treatment, and the development of chronic TMD.

*o.slesarev@gmail.com 
The objective of this study was to perform an analysis of the patient complaints of the structure and pattern of the formation of clinical diagnosis in patients with TMD.

\section{MATERIALS AND METHODS}

Twenty-eight men (15.9\%) and 148 women (84.1\%) were examined (average ages, $36.9 \pm 9.2$ years for men, 41.0 \pm 3.4 years for women). We studied 176 X-ray protocols (604 tomograms) of patients with TMD. Diagnostic study criteria for temporomandibular disorders were used. Targeted linear tomography of the TMJ, cone beam computed tomography (CBCT) by individual landmarks and craniometry of the tomograms of the temporomandibular joint (Slesarev O.V., 2013) were used in the next five years.

Clinical diagnostics of the psychological phenomena and communicative deviations was performed by interview as described by Rogers [2]. Patients were assigned to groups A ( 38 patients) and B (23 patients) based on the nature of the psychological phenomena and communicative deviations.

Statistical analysis of the data was performed with the use of IBM SPSS Statistics 21 (license No. 20130626-3). Statistical processing included the analysis of the contingency tables by the Chi-square criterion. The critical mean of the significance level was accepted as 0.05 .

\section{STUDY RESULTS}

We examined 28 men (15.9\%) and 148 women (84.1\%) (average ages, 36.9 \pm 9.2 years for men, and
41.0 \pm 3.4 years for women). Most patients (125 individuals, $71 \%$ ) were referred for $\mathrm{x}$-ray with a clinical diagnosis of arthrosis and arthritis, 29 individuals (16.5\%) with a diagnosis of luxation and subluxation of the articular head of one or two joints, and 22 patients (12.5\%) with a diagnosis of TMJ dysfunction with limited mobility. Forty-two patients (23.7\%) had X-ray TMJ films as recommended a century ago by Shuller, and 25 patients (14.2\%) had standard orthopantomograms. Of the 102 individuals examined, $57.9 \%$ had long-term disease anamnesis (3-5 years). Patients either received no treatment due to an unknown diagnosis or were observed by a neuropathologist due to trigeminal neuritis or by an otolaryngologist due to otitis. Forty-nine individuals (28\%) clearly associated the appearance of the disease symptoms with a visit to a dentist for the purpose of the extraction of molar teeth, dental treatment, or prosthetics. Continuous opening of the mouth was observed in all the cases.

Analysis of the case reports showed occlusion anomalies in 35 patients (19.9\%) and the absence of bruxism (tooth grinding) on both sides or on one side of the mandibular jaw over the preceding 2 to 3 years in 26 patients (14.8\%). Nineteen patients (10.8\%) had trauma to the mandibular jaw in anamnesis, and 11 had intra-articular fractures of the condylar process. Twenty-two patients (12.5\%) were referred for linear TMJ tomography with a diagnosis of joint dysfunction with limited mobility of the articular heads. Targeted linear tomography illustrated the differences between the referred clinical diagnosis and definitive diagnosis as confirmed by X-ray. The combination of functional disorders with the degenerative dystrophic changes of the joint components was significant (Table 1).

Table 1. Interpretation of x-ray images by the results of the examination of 176 patients with TMJ pathology with the use of linear tomography

\begin{tabular}{|c|l|c|l|l|l|}
\hline \multirow{2}{*}{$\begin{array}{l}\text { X-ray } \\
\text { norm }\end{array}$} & \multicolumn{2}{|l|}{ Functional disorders } & \multicolumn{2}{|c|}{$\begin{array}{l}\text { Inflammatory degenerative } \\
\text { dystrophic disorders }\end{array}$} \\
\cline { 2 - 6 } & $\begin{array}{l}\text { Subluxation and luxation of the } \\
\text { head }\end{array}$ & Limited function & Arthritis & Arthrosis $\begin{array}{l}\text { Deforming } \\
\text { arthrosis }\end{array}$ \\
\hline 16 & 75 & 56 & 19 & 31 & 67 \\
\hline 16 & \multicolumn{2}{|c|}{731} & & & 117 \\
\hline
\end{tabular}

Moreover, malformation of the bony components of the joints, such as dysplasia and asymmetry of the condylar processes in the form of augmentation of one by $3-5 \mathrm{~mm}$, was revealed in 37 individuals. Malformation of the condylar process was combined with such pathology as the habitual anterior subluxation and luxation of the articular head with signs of arthrosis and arthritis of the TMJ. Clinical manifestation of dysfunction, arthrosis and arthritis of the joints (pain and mobility disorders of the mandibular jaw) was the cause of the patients' visit to a dentist. We determined that the intensity of anatomical and functional TMD disorders in women, as detected by X-rays, was not similar and corresponded to the reproductive period (Table 2 ). 
Table 2. Pattern of X-ray TMD disorders in women during different stages of reproduction

\begin{tabular}{|c|c|c|c|c|c|c|c|c|}
\hline $\begin{array}{l}\text { Reproductive } \\
\text { stage }\end{array}$ & Age & $\begin{array}{l}\text { X-ray } \\
\text { norm }\end{array}$ & $\begin{array}{c}\text { Limitation } \\
\text { of joint } \\
\text { mobility }\end{array}$ & $\begin{array}{l}\text { Subluxation } \\
\text { of the head }\end{array}$ & $\begin{array}{c}\text { Luxation } \\
\text { of the } \\
\text { head }\end{array}$ & Arthritis & $\begin{array}{l}\text { Sclerosing } \\
\text { arthrosis }\end{array}$ & $\begin{array}{l}\text { Deforming } \\
\text { arthrosis }\end{array}$ \\
\hline $\begin{array}{l}\text { 1. Prepubertal } \\
\text { ( } 3 \text { individuals) }\end{array}$ & $\begin{array}{l}\text { up to14 } \\
\text { years }\end{array}$ & $0.0 \%$ & $25.0 \%$ & $25.0 \%$ & $0.0 \%$ & $75.0 \%$ & $0.0 \%$ & $0.0 \%$ \\
\hline $\begin{array}{l}\text { 2. Pubertal } \\
\text { (24 individuals) }\end{array}$ & $\begin{array}{l}14-18 \\
\text { years }\end{array}$ & $3.0 \%$ & $44.4 \%$ & $30.6 \%$ & $13.9 \%$ & $11.1 \%$ & $22.2 \%$ & $33.3 \%$ \\
\hline $\begin{array}{l}\text { 3. Early } \\
\text { (40 individuals) }\end{array}$ & $\begin{array}{l}19-35 \\
\text { years } \\
\end{array}$ & $10.0 \%$ & $17.6 \%$ & $48.5 \%$ & $16.2 \%$ & $13.2 \%$ & $19.4 \%$ & $35.2 \%$ \\
\hline $\begin{array}{l}\text { 4. Late } \\
\text { (43 individuals) }\end{array}$ & $\begin{array}{l}36-45 \\
\text { years }\end{array}$ & $9.0 \%$ & $40.0 \%$ & $20.0 \%$ & $8.6 \%$ & $10.0 \%$ & $15.7 \%$ & $52.8 \%$ \\
\hline $\begin{array}{l}\text { 5. Perimenopause } \\
\text { (16 individuals) }\end{array}$ & $\begin{array}{l}46-55 \\
\text { years }\end{array}$ & $7.0 \%$ & $42.8 \%$ & $39.3 \%$ & $0.0 \%$ & $10.7 \%$ & $14.3 \%$ & $50.0 \%$ \\
\hline $\begin{array}{l}\text { 6. Postmenopause } \\
\text { (22 individuals) }\end{array}$ & $\begin{array}{c}>56 \\
\text { years }\end{array}$ & $8.0 \%$ & $25.0 \%$ & $30.6 \%$ & $5.5 \%$ & $30.8 \%$ & $27.8 \%$ & $30.6 \%$ \\
\hline p1-2 & & 0.110 & 0.983 & 0.639 & 0.810 & 0.056 & 0.887 & 0.603 \\
\hline p1-3 & & 0.649 & 0.648 & 0.852 & 0.936 & 0.054 & 0.949 & 0.538 \\
\hline p1-4 & & 0.594 & 0.923 & 0.593 & 0.570 & 0.024 & 0.920 & 0.241 \\
\hline p1-5 & & 0.388 & 0.948 & 0.857 & & 0.082 & 0.789 & 0.331 \\
\hline p1-6 & & 0.487 & 0.477 & 0.636 & 0.309 & 0.393 & 0.738 & 0.669 \\
\hline p2-3 & & 0.587 & 0.042 & 0.253 & 0.912 & 0.885 & 0.959 & 0.907 \\
\hline p2-4 & & 0.669 & 0.927 & 0.498 & 0.793 & 0.783 & 0.740 & 0.200 \\
\hline p2-5 & & 0.858 & 0.822 & 0.819 & 0.330 & 0.633 & 0.832 & 0.467 \\
\hline p2-6 & & 0.923 & 0.286 & 0.749 & 0.646 & 0.198 & 0.922 & 0.904 \\
\hline p3-4 & & 0.826 & 0.045 & 0.012 & 0.472 & 0.911 & 0.877 & 0.164 \\
\hline p3-5 & & 0.872 & 0.103 & 0.743 & 0.211 & 0.848 & 0.949 & 0.471 \\
\hline p3-6 & & 0.843 & 0.716 & 0.273 & 0.412 & 0.180 & 0.659 & 0.932 \\
\hline p4-5 & & 0.779 & 0.918 & 0.238 & 0.544 & 0.685 & 0.784 & 0.919 \\
\hline p4-6 & & 0.741 & 0.355 & 0.520 & 0.961 & 0.078 & 0.407 & 0.150 \\
\hline p5-6 & & 0.613 & 0.420 & 0.832 & 0.986 & 0.283 & 0.552 & 0.382 \\
\hline
\end{tabular}

Note: Percentages were calculated from raw numbers in the age range of each group; the sum of the percentages was more than $100 \%$ due to the presence of simultaneous cases of combined pathologies.

Comparative analysis of the frequency of occurrence of the x-ray changes in the TMJ by age showed the following: Limitations in the physiological mobility of the mandibular jaw head were observed predominantly in the 2 nd, $4^{\text {th }}$, and 5 th periods (periods 3 and 2, p=0.042; periods 3 and 4, $\mathrm{p}=0.045$ ); subluxation of the head in the 3 rd and $5^{\text {th }}$ periods (periods 3 and 4, $\mathrm{p}=0.012$ ); and symptoms of arthritis in the 1st period (periods 1 and 4: $\mathrm{p}=0.024$ ). No statistically significant age-related changes were revealed in the other X-ray images, due predominantly to the small sample size. Trends toward a higher frequency of habitual luxation were observed in the 2nd and 3rd periods, toward sclerosing arthrosis in the 2nd and 6th periods, and toward deforming arthrosis in the 4th and 5th periods. Analysis by age group demonstrated the most characteristic data: In the pubertal period, limitations in joint mobility (44.4\%, $\mathrm{p}=0.045$, compared with head luxation and arthritis, $\mathrm{p}=0.024$ ) dominated. In the early reproductive period, head subluxation dominated $(48.5 \%, \mathrm{p}<0.010$, with all types of pathology detected except deforming arthrosis). In the late reproductive period and perimenopause, half of the examined individuals demonstrated deforming arthrosis $(52.8 \%$ in the late reproductive period, $\mathrm{p}<0.01$, with all types of pathology detected except limited joint mobility); and 50\% in perimenopause ( $\mathrm{p}<0.05$ with the X-ray norm, head luxation, and arthritis) and in postmenopause (arthritis and sclerosing arthrosis, 30.8\% and 27.8\%, respectively).

We assessed the patterns of deviation in the patients' behavior according to the signs of chronic pain syndrome and revealed the phenomenological dysfunctions masked by the complaints associated with other disorders. Patients were assigned to group A or group B (Table 3) based on the pattern of the clinical manifestation of psychological phenomena and communicative deviations. 
Table 3. Patterns of the clinical manifestation of psychological phenomena and

communicative deviations in TMD patients with chronic pain ( $\mathrm{n}=$ number of patients)

\begin{tabular}{|c|c|c|c|c|}
\hline $\begin{array}{l}\text { Leading symptom } \\
\text { complex }\end{array}$ & Behavioral pattern & $\begin{array}{l}\text { Type of attitude toward } \\
\text { the disease }\end{array}$ & Value cluster & $\begin{array}{c}\text { Characteristics of } \\
\text { the formation and } \\
\text { translation of the } \\
\text { pain }\end{array}$ \\
\hline $\begin{array}{l}\text { Group A } \\
(\mathrm{n}=38)\end{array}$ & $\begin{array}{l}\text { Social adaptation } \\
\text { unaffected }\end{array}$ & $\begin{array}{l}\text { Harmonic, ergopathic, } \\
\text { anosognosic }\end{array}$ & $\begin{array}{l}\text { Motivation for the } \\
\text { solution of a problem }\end{array}$ & Nociceptive pain \\
\hline $\begin{array}{l}\text { Group B } \\
(n=23)\end{array}$ & $\begin{array}{l}\text { Somatization by } \\
\text { mental rigidity }\end{array}$ & $\begin{array}{l}\text { Intrapsychic } \\
\text { determination. Disease } \\
\text { as the authentic project } \\
\text { of a psychological } \\
\text { behavioral model } \\
\text { implementing neurotic } \\
\text { demand. }\end{array}$ & $\begin{array}{l}\text { Motivation for the } \\
\text { demonstration of a } \\
\text { problem in the scope of } \\
\text { the project of a } \\
\text { psychological behavioral } \\
\text { model; compensation } \\
\text { requirements. }\end{array}$ & Neuropathic pain \\
\hline
\end{tabular}

\section{CONCLUSIONS}

The formation of clinical groups of patients with TMD is determined by the place of the primary treatment, specialization of the institution, and the validity of techniques for the primary diagnosis of TMD. This affects the patients' quality of routing and is a cause of chronic (58\%) disease. A disease course with alternating periods of active symptoms and relative improvement of the condition creates a false picture of treatment efficacy [1]. The intensity of pain corresponds to the nature of pain behavior. X-ray design and functional status elements TMJ the same type with different degrees of intensity of pain, which is consistent with the results of the study $[13 ; 14]$. In TMD therapy, the diagnosis of a type of pain behavior in the scope of the authentic value cluster is critical for the patient.

Visualization of the components of TMJ plays a decisive role in the statement of a definitive diagnosis and the planning of therapy. The patient complaints structure is inhomogenous and is related to the reproductive period in women (prevalence, $84.1 \%$ ), and the highest appealability belongs to the early and late reproductive periods (56\%). The combination of functional and degenerative dystrophic disorders is observed, with notable domination of functional disorders in different combinations of the clinical forms.

In group A (63\% of the cases analyzed), somatic disorders with the manifestation of behavioral deviations at the level of a phenomenon (neurovegetative or occlusive imbalance, iatrogenia) were revealed. These refer to harmonic, ergopathic, and anosognosic patterns by the type of psychological reaction. Detected clinical phenomena proved no significant disorders of the adaptation and showed that nonspecific symptoms of psychic disorders, including pain, had normal and average values (Table 3). We defined the character of the formation and translation of pain as nociceptive. Patients in this group required a psychological consultation. In group B (37\% of cases analyzed), somatic and psychosomatic disorders with the manifestation of behavioral deviations at the symptom level were revealed, and in $20 \%$ of these, an attribution condition (anxiety, hypochondria, neurasthenia, iatrogenia, and compensation requirements) was detected. This was the most difficult group of patients, who referred themselves after several unsuccessful treatment attempts in other clinics, and these patients constituted $6 \%$ of our general observations. The type of reaction in a disease with intrapsychic direction by articulation disorders was characterized with a low threshold of pain perception and moderate or severe depression (Table 3). We determined the character of the mechanism of pain formation and translation to be neuropathic, persistent long-term pain. Sensory phenomena were detected, specifically, paresthesias and dysesthesias that manifested clinically as complaints of loss of sensation or tingling of the skin in the projection of the lateral pole of the TMJ head and of the anterior half of the auricle, lasting from several seconds to several days.

Acknowledgement: The study was performed without financial support. The authors have no conflict of interest.

\section{REFERENCES}

1. J.P. Okeson, Management of Temporomandibular Disorders and Occlusion, 4th ed., New York (NY), USA: MOSBY, 1998, p. 638.

2. C. R. Rogers, "The necessary and sufficient conditions of therapeutic personality change," Journal of Consulting Psychology, vol. 21, no. 2, pp. 95-103, Apr. 1957.

DOI: $10.1037 /$ hoo 45357

3. Н. А. Рабухина, А. П. Аржанцев, “Панорамная томография в диагностике дисфункций височнонижнечелюстного сустава," Визуализация в клинике, т. 1, но. 2, стр. 47-52, Мар. 1993. (N. A. Rabukhnia, A. P. Arzhantsev, "Panoramic tomography in the diagnostics of diseases of the temporomandibular joint," Visualization in the clinics, vol. 1, no. 2, pp. 47-52, Mar. 1993.)

4. R. J. Gatchel, Clinical Essentials of Pain Management. Washington (DC), USA: American Psychological Association Press, 2005.

5. В. П. Потапов, “Клиническая картина и тактика лечения больных с нейромускулярным дисфункциональным синдромом височнонижнечелюстного сустава," Саратовский научномедицинский журнал, т. 5, но. 1, стр. 95-97, 2009 (V. P. Potapov, "Clinical picture and approaches to a 
treatment of patients with the neuromuscular dysfunctional syndrome of the temporomandibular joint," Saratov Scientif. Med. J., vol. 5, no. 1, pp. 95-97, 2009.)

Retrieved from:

http://www.ssmj.ru/system/files/archive/ssmj-20091-full.pdf

Retrieved on: Jan. 23, 2017

6. M. D. Wise, Failure in the restored dentition: management and treatment, 1st ed., London, UK: Quintessence, 1995.

7. G. E. Carlsson, "Epidemiology and treatment need for temporomandibular disorders," J. Orofac. Pain, vol. 13, no. 4, pp. 232-237, 1999. PMid: 10823035

8. D. A. Gonçalves, A. L. Dal Fabbro, J.A. Campos, M. E. Bigal, J. G. Speciali, "Symptoms of temporomandibular disorders in the population: an epidemiological study," J. Orofac. Pain, vol. 24, no. 3 , pp. $270-278,2010$

PMid: 20664828

9. Д. А. Трунин, О. В. Слесарев, "Характер нарушения филогенетически детерминированных критериев артикуляционной нормы в онтогенезе, выявляемый на диагностическом этапе у пациентов с неартикулярными расстройствами височнонижнечелюстного сустава," Современные проблемы науки и образования, но. 4, Июль, 2014. (D. A. Trunin, O. V. Slesarev, "Character of the disorders of the phylogenetically determined criteria of the articulation norm in the ontogenesis detected at the diagnostic stage in patients with non-articular disorders of the temporomandibular joint", Modern Iss. Sci. Ed., no. 4, 2014.)

Retrieved from:

https://www.science-

education.ru/ru/article/view?id=14106

Retrieved on: Jan. 17, 2017
10. C. S. Greene, D. M. Laskin, "Temporomandibular Disorders: Moving to a Medically Based Model," J. Dent. Res., vol. 79, no. 10, pp. 1736-1739, Oct. 2000. DOI: 10.1177/00220345000790100101 PMid: 11077987

11. О.В. Слесарев, "Методика краниометрии томограмм височно-нижнечелюстного сустава человека," Вестник РНЦРР, Ноя. 2013. (O. V. Slesarev, "Methodology of the craniometrics of human temporomandibular joint tomograms," Bull. Russian Scientif. Centre X-ray Radiol., Nov. 2013.)

Retrieved from:

http://vestnik.rncrr.ru/vestnik/v13/papers/slesarev_v1 3.htm

Retrieved on: Jan. 10, 2017

12. W. K. Solberg, M. W. Woo, J. B. Houston, "Prevalence of mandibular dysfunction in young adults," $J . A m$. Dent. Assoc., vol. 98, no. 1, pp. 25-34, Jan. 1979.

DOI: $10.14219 /$ jada.archive.1979.0008 PMid: 282342

13. S. L. Kraus, "Characteristics of 511 patients with temporomandibular disorders referred for physica therapy," Oral Surgery, Oral Medicine, Oral Pathology, Oral Radiology, vol. 118, no. 4, pp. $432-$ 439, Oct. 2014.

DOI: 10.1016/j.000o.2014.06.005

PMid: 25240990

14. Y. M. Costa et al., "Temporomandibular disorders and painful comorbidities: clinical association and underlying mechanisms," Oral Surgery, Oral Medicine, Oral Pathology, Oral Radiology, vol. 123, no. 3, pp. 288 - 297, Mar. 2017.

DOI: 10.1016/j.0000.2016.12.005

PMid: 28153123 